\title{
Pengaruh Kecepatan, Temperatur dan Infill Terhadap Kualitas dan Kekasaran Kotak Relay Lampu Sign Sepedamotor Hasil dari 3D Printing
}

\author{
Joy H Panjaitan ${ }^{1}$, Miduk Tampubolon ${ }^{2}$, Fiktor Sihombing ${ }^{3}$, Jamser Simanjuntak ${ }^{3}$ \\ ${ }^{1}$ Mahasiswa Prodi Teknik Mesin, Universitas HKBP Nommensen, Medan \\ ${ }^{2}$ Prodi Teknik Mesin, Universitas HKBP Nommensen, Medan \\ ${ }^{3}$ Prodi Teknik Elektro, Universitas HKBP Nommensen, Medan
}

\begin{abstract}
3D printing technology has great potential in today's manufacturing world where one of its uses is in the prototype of a product. One of the most famous and inexpensive 3D printing technologies is the Fused Deposition Modeling (FDM) method. Many studies have been carried out using this FDM method.

In this study, the printing of motorbike light relay boxes was carried out using the FDM method with two variations of speed, temperature and infill of each mass. 3D Printing uses a nozzle diameter of $0.4 \mathrm{~mm}$ and a work table temperature of $60 \mathrm{oC}$ and a height of $0.2 \mathrm{~mm}$ for each layer with support every where. From the research results, all the products produced have a rough surface with a level of geometric accuracy ranging from $0.91 \%$ for the length dimension and $7.73 \%$ for the width dimension of the product.
\end{abstract}

Keywords : 3D printing, speed, temperature, infill, roughness

\section{PENDAHULUAN}

Beragam teknologi muulai dikembangkan dalam mendesain dan memproduksi suatu produk dan menjadi bagian yang sangat penting dalam industri manufaktur mengingat begitu ketatnya persaingan dan cepatnya inovasi-inovasi yang dikeluarkan oleh produsen untuk mendapatkan pasar penjualan [1]. Teknik pencetakan 3D merupakan salah satu perkembangan teknologi terkini dalam mengantisipasi ketatnya persaingan dan cepatnya inovasi-inovasi produk tersebut. Umumnya produk tersebut selalu melalui proses pembuatan desain dan produk awal atau prototipe.

Dalam pembuatan prototipe tersebut, teknologi pencetakan 3D atau 3D printing semakin banyak digunakan saat ini. Salah satu keuntungan utama dari 3D printing adalah kemampuan untuk menghasilkan bentuk atau geometri yang sangat kompleks, dan prasyarat untuk memproduksi bagian cetak 3D adalah model 3D digital atau file CAD. Proses 3D printing yang paling umum digunakan adalah teknik ekstrusi bahan yang disebut fused deposition modeling (FDM) [2]. Teknik pencetakan 3D ini memungkinkan realisasi fisik model Computer Aided Design (CAD) 3D dengan mengimplementasikan penambahan bahan lapis demi lapis, dengan demikian menghasilkan objek fisik 3D yang memiliki struktur yang sama dengan model digital [3].

Parameter parameter yang umum digunakan dalam pencetakan 3D dengan metode FDM ini adalah kecepatan gerak printer untuk membuat pola (print speed), ketebalan atau ketinggian atau jarak per layer (layer height), dan texsture plastik cair yang disebabkan suhu cetak (printing temperature) dimana suhu cetak ini dipengaruhi oleh suhu nozzle dan suhu landasan. Parameter parameter ini tidak memiliki nilai pasti dalam 
pengerjaannya sehingga perlu dicari nilai yang sesuai untuk meperoleh hasil yang terbaik [4].

Beberapa penelitian terkait pencetakan 3D ini telah dilakukan diantaranya penelitian yang dilaksanakan oleh Sobron Lubis untuk mengetahui pengaruh posisi objek dalam pembuatan protipe cepat (rapid prototyping) dengan menggunakan 3D printing untuk bahan polymer PLA dan ABS terhadap kekuatan tarik maupun ketelitian dimensi yang dihasilkan [5]. Sementara itu hamid Abdillah dan Ulikaryani mencoba mengamati penggunaan 3D printer FDM dalam mengatasi msalah pembuatan pola cor pada industry pengecoran logam [6]. Begitu juga dengan Ikhwan taufik dkk telah melakukan penelitian untuk melihat pengaruh kecepatan printing terhadap kekasaran permukaan dengan bahan baku pilamen PLA dan specimen berbentuk kubus [7]. Sementara itu Benny dkk telah melakukan penelitian untuk mengamati pengaruh temperature nozzle dan meja landasan terhadap densitas dan kekasaran permukaan dari produk berbentuk kubus dengan bahan baku pilamen ABS [8].

Berdasarkan hasil peneltian para peneliti sebelumnya, peneliti tertarik untuk langsung membuat suatu produk jadi dengan menggunakan mesin $3 D$ Printing dengan kategori Material Extrusion dengan jenis Fused Deposition Modeling (FDM) dan berbahan baku pilamen Polylactic Acid (PLA) dengan memvariasikan kecepatan printing, temperature nozzle dan persentase material pengisi (infill).

\section{METODOLOGI PENELITIAN}

Pada penelitian ini akan diamati pengaruh dari kecepatan printing, suhu nozzle dan persentase material pengisi (infill) terhadap kualitas (dimensi) dan kekasaran dari kotak relay lampu sign sepedamotor yang dibuat, sebagaimana gambar 1 dan 2 berikut ini.

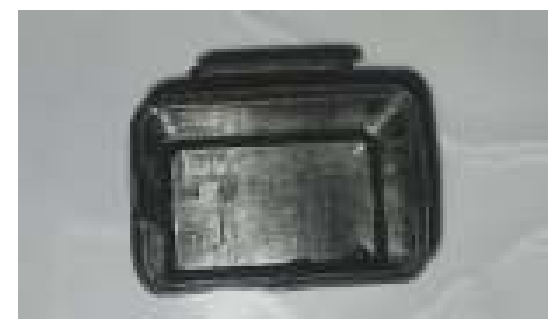

Gambar 1. Kotak Relay Lampu Sign Sepedamotor 


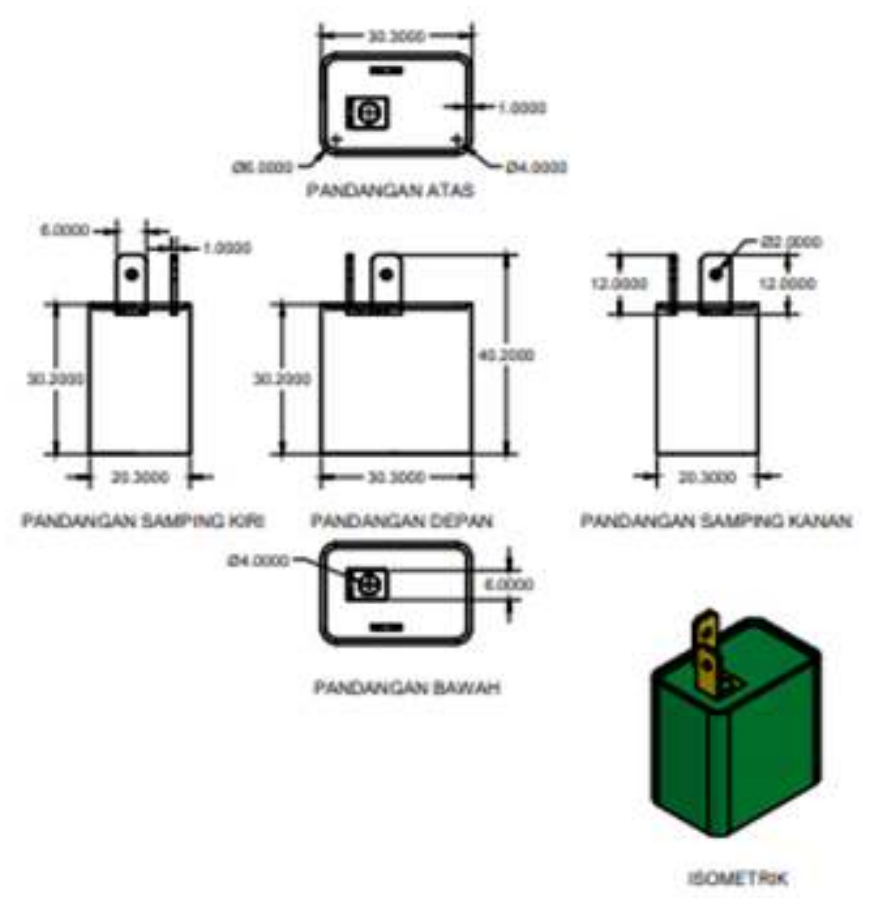

Gambar 2. Desain Teknik Kotak Relay

Proses manufaktur printer 3D tergantung pada settingan pada aplikasi slicer. Setelah format file yang digambar dibuat ke format STL atau .stl. Pada printer 3D diperlukan setting parameter yang akurat, seperti pengaturan ketebalan dinding, pengisi, temperature PLA, temperature meja kerja, kecepatan printer, support, dan lain-lain. Selain parameter-parameter tersebut posisi penempatan objek juga sangat berpengaruh dalam keberhasilan printer dalam membuat produk, karena apabila objek yang akan dicetak memiliki banyak sudut-sudut atau bagian yang menggantung maka dalam hal ini sangat diperlukan pengaturan support dalam tahap slicing. Dalam hal ini penulis mengambil posisi horizontal, dengan posisi seperti ini akan menghasilkan permukaan atas 3D objek yang halus. Posisi ini memerlukan banyak support namun hanya mulai bagian tengah sampai dasar yang memerlukan support, sehingga bentuk permukaan atas objek tidak akan dipengaruhi oleh support.

Parameter tetap yang digunakan adalah:

- Proses slicing menggunakan : ultimaker cura

- Diameter Nozzel : $0.4 \mathrm{~mm}$

- Jenis filament : PLA

- Infil patrern : line (garis)

- Infil support: 15\%

- Build plate temperature : $60^{\circ}$

- Layer height : $0.2 \mathrm{~mm}$

- Wall thickness : $0.8 \mathrm{~mm}$

Parameter tetap yang divariasikan adalah:

- Infil (pengisi) : 20\% dan 30\%

- Print speed : $100 \mathrm{~mm} / \mathrm{s}$ dan $120 \mathrm{~mm} / \mathrm{s}$

- Printing temperature : $190^{\circ} \mathrm{C}$ dan $200^{\circ} \mathrm{C}$

Parameter yang akan diamati adalah : 
- Dimensi akhir dari kotak relay

- Kekasaran permukaan dari kotak relay diukur dengan menggunakan surface roughness tester Mitutoyo SURFTEST SJ-210 sepanjang keempat garis seperti pada gambar 3 .

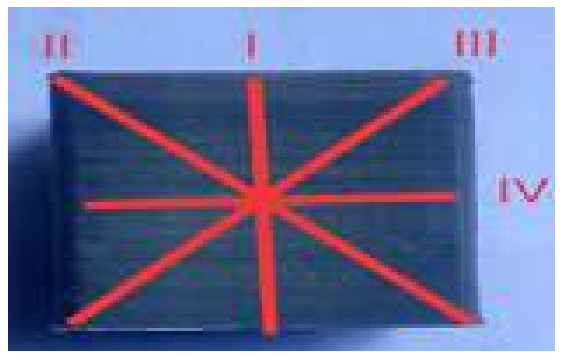

Gambar 3. Posisi garis pengukuran kekasaran permukaan pada setiap percobaan

\section{HASIL DAN PEMBAHASAN}

\subsection{Proses Manufaktur}

Spesimen I

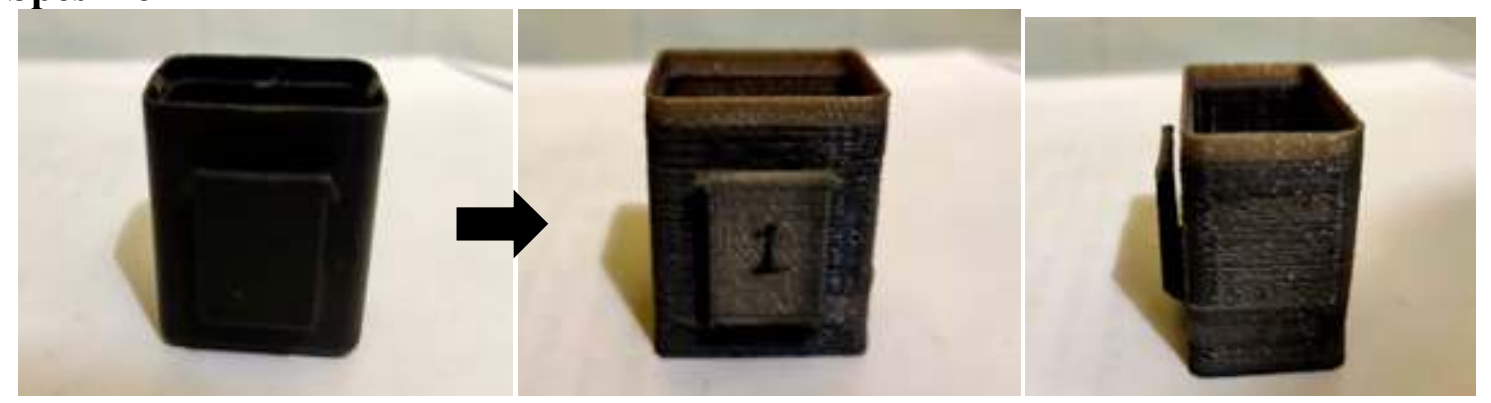

Parameter yang divariasikan dan diamati adalah sebagai berikut :

- Infil (pengisi) : 30\%

- Waktu Print pada software ultimaker cura : 27 menit

- Panjang PLA yang dibutuhkan dalam proses manufaktur : 2,73 m

- Print speed : $100 \mathrm{~mm} / \mathrm{s}$

- Printing temperature $: 190^{\circ} \mathrm{C}$

- Panjang: $33 \mathrm{~mm}$

- Lebar: $22 \mathrm{~mm}$

- Tebal : $1.88 \mathrm{~mm}$

Dari hasil pengukuran kekasaran permukaan untuk specimen I sebanyak empat kali pengukuran seperti pada gambar 3, diperoleh rata-rata kekasaran untuk masing-masing pengukuran dan spesimen pertama adalah :

1. Rata-rata kekasaran pada pengukuran di garis 1 adalah $\mathrm{Ra}=10,605 \mu \mathrm{m}$, Gambar 4 .

2. Rata-rata kekasaran pada pengukuran di garis 2 adalah $\mathrm{Ra}=16,868 \mu \mathrm{m}$.

3. Rata-rata kekasaran pada pengukuran di garis 3 adalah $\mathrm{Ra}=13,381 \mu \mathrm{m}$.

4. Rata-rata kekasaran pada pengukuran di garis 4 adalah $\mathrm{Ra}=13,677 \mu \mathrm{m}$. 


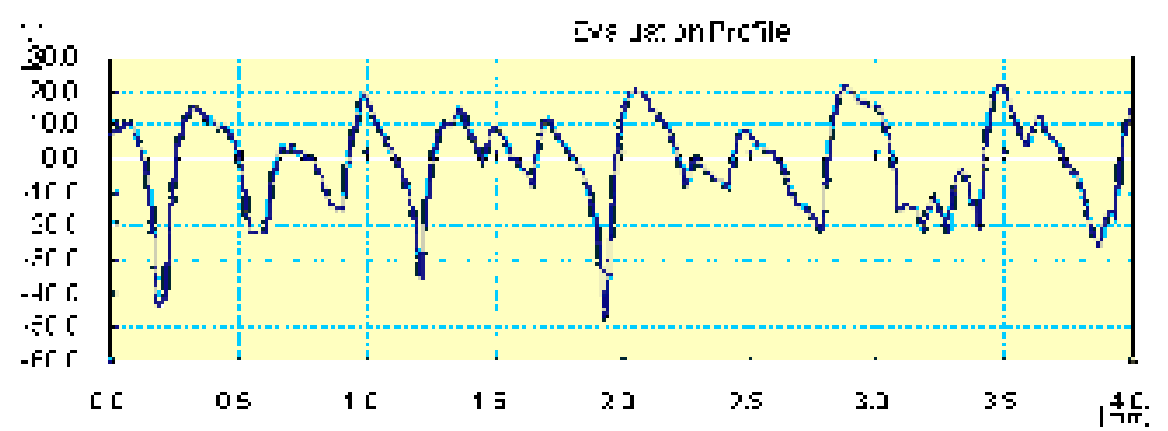

Gambar 4. Grafik rata-rata kekasaran pada pengukuran di garis $1(\mathrm{Ra}=10,605 \mu \mathrm{m})$ pada spesimen I

Sehingga rata-rata kekasaran permukaan hasil pencetakan 3D untuk spesimen I adalah $\mathrm{Ra}=13,633 \mu \mathrm{m}$, yang berarti hasil permukaan yang dicetak dengan $3 \mathrm{D}$ printer ini termasuk permukaan kasar sebagaimana pada tabel 1 berikut.

Tabel 1. Angka kekasaran permukaan dan sifatnya

\begin{tabular}{|c|c|c|c|}
\hline No & ISO Number & $\begin{array}{c}\text { Mean Raughness } \\
(\mathrm{Ra} ; \mu \mathrm{m})\end{array}$ & Keterangan \\
\hline 1 & N12 & 50.0 & \multirow{2}{*}{ Sangat Kasar } \\
\hline 2 & N11 & 25.0 & \\
\hline 3 & N10 & 12.5 & \multirow{2}{*}{ Kasar } \\
\hline 4 & N9 & 6.3 & \\
\hline 5 & N8 & 3.2 & \multirow{3}{*}{ Normal } \\
\hline 6 & N7 & 1.6 & \\
\hline 7 & N6 & 0.8 & \\
\hline 8 & N5 & 0.4 & \multirow{2}{*}{ Halus } \\
\hline 9 & N4 & 0.2 & \\
\hline 10 & N3 & 0.1 & \multirow{3}{*}{ Sangat halus } \\
\hline 11 & $\mathrm{~N} 2$ & 0.05 & \\
\hline 12 & N1 & 0.025 & \\
\hline
\end{tabular}

\section{Spesimen II}

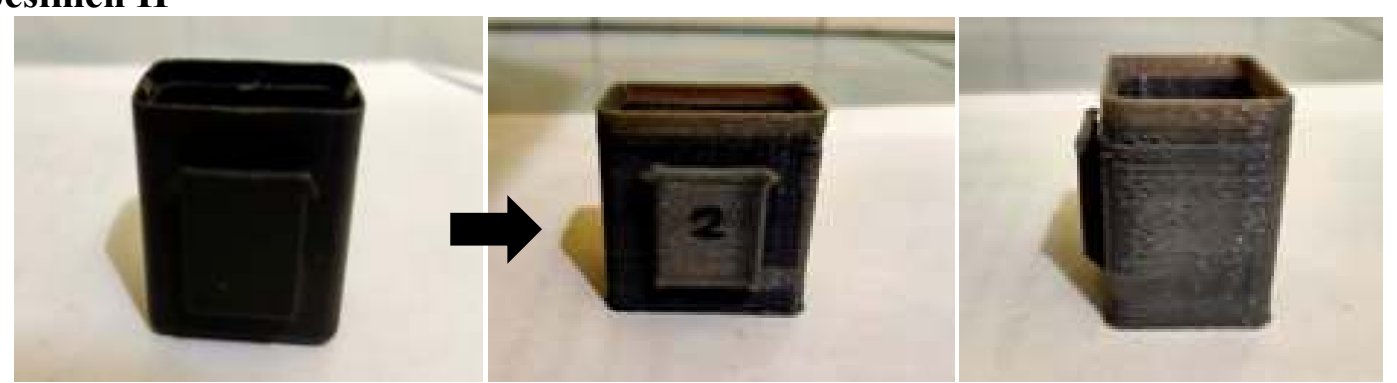

Parameter yang divariasikan dan diamati adalah sebagai berikut :

- Infil (pengisi) : 30\%

- Waktu Print pada software ultimaker cura : 27 menit

- Panjang PLA yang dibutuhkan dalam proses manufaktur : $2.73 \mathrm{~m}$

- Print speed : $100 \mathrm{~mm} / \mathrm{s}$ 
- Printing temperature : $200^{\circ}$

- Panjang: $33 \mathrm{~mm}$

- Lebar : $22 \mathrm{~mm}$

- Tebal : $1.72 \mathrm{~mm}$

Dari hasil pengukuran kekasaran permukaan untuk specimen II sebanyak empat kali pengukuran seperti pada gambar 3, diperoleh rata-rata kekasaran untuk masing-masing pengukuran dan spesimen kedua adalah :

1. Rata-rata kekasaran pada pengukuran di garis 1 adalah $\mathrm{Ra}=21,845 \mu \mathrm{m}$, Gambar 5 .

2. Rata-rata kekasaran pada pengukuran di garis 2 adalah $\mathrm{Ra}=17,362 \mu \mathrm{m}$.

3. Rata-rata kekasaran pada pengukuran di garis 3 adalah $\mathrm{Ra}=19,800 \mu \mathrm{m}$.

4. Rata-rata kekasaran pada pengukuran di garis 4 adalah $\mathrm{Ra}=19,804 \mu \mathrm{m}$.

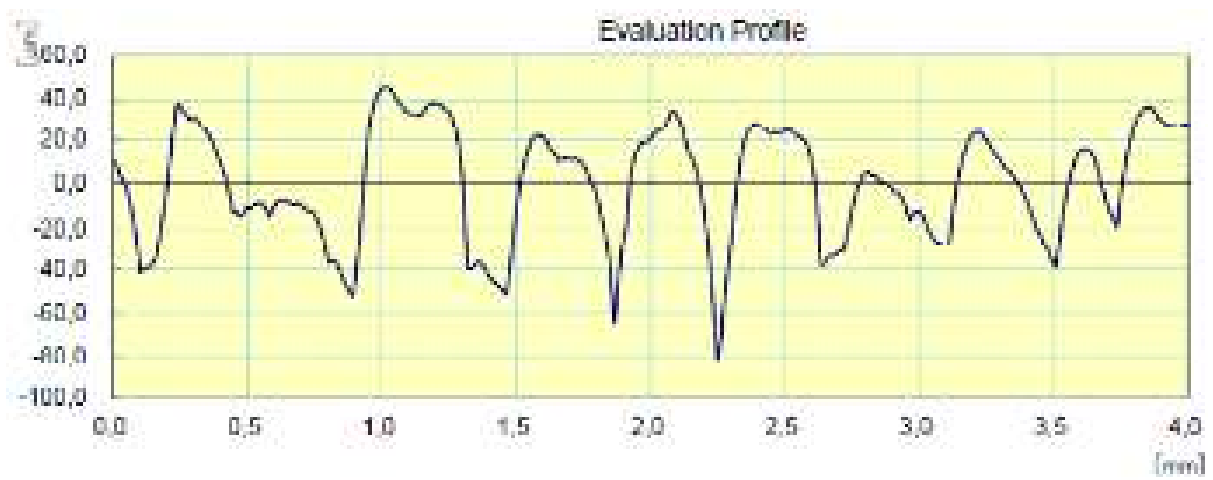

Gambar 5. Grafik rata-rata kekasaran pada pengukuran di garis $1(\mathrm{Ra}=21,845 \mu \mathrm{m})$ pada spesimen II

Sehingga rata-rata kekasaran permukaan hasil pencetakan 3D untuk spesimen II adalah $\mathrm{Ra}=19,703 \mu \mathrm{m}$, yang berarti hasil permukaan yang dicetak dengan 3D printer ini termasuk permukaan kasar sebagaimana pada tabel 1 .

\section{Spesimen III}

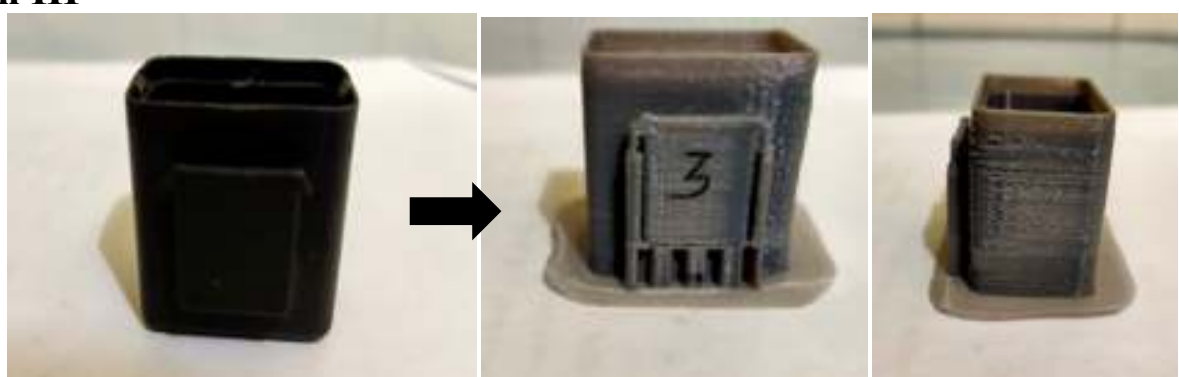

Parameter yang divariasikan dan diamati adalah sebagai berikut :

- Infil (pengisi) : 20\%

- Waktu Print pada software ultimaker cura : 27 menit

- Panjang PLA yang dibutuhkan dalam proses manufaktur : $2.73 \mathrm{~m}$

- Print speed $: 100 \mathrm{~mm} / \mathrm{s}$

- Printing temperature $: 190^{\circ}$

- Panjang: $33 \mathrm{~mm}$

- Lebar: $22 \mathrm{~mm}$

- Tebal : $1.62 \mathrm{~mm}$ 
Dari hasil pengukuran kekasaran permukaan untuk spesimen III sebanyak empat kali pengukuran seperti pada gambar 3, diperoleh rata-rata kekasaran untuk masing-masing pengukuran dan spesimen ketiga adalah :

1. Rata-rata kekasaran pada pengukuran di garis 1 adalah $\mathrm{Ra}=15,902 \mu \mathrm{m}$, Gambar 6 .

2. Rata-rata kekasaran pada pengukuran di garis 2 adalah $\mathrm{Ra}=11,966 \mu \mathrm{m}$.

3. Rata-rata kekasaran pada pengukuran di garis 3 adalah $\mathrm{Ra}=12,162 \mu \mathrm{m}$.

4. Rata-rata kekasaran pada pengukuran di garis 4 adalah $\mathrm{Ra}=12,150 \mu \mathrm{m}$.

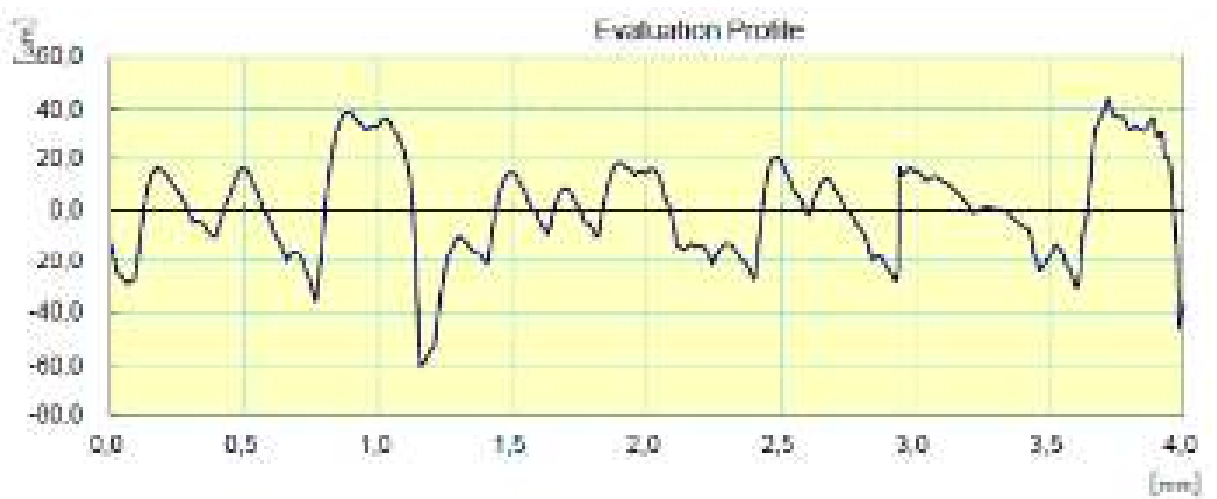

Gambar 6. Grafik rata-rata kekasaran pada pengukuran di garis $1(\mathrm{Ra}=15,902 \mu \mathrm{m})$ pada spesimen III

Sehingga rata-rata kekasaran permukaan hasil pencetakan 3D untuk spesimen III adalah $\mathrm{Ra}=13,045 \mu \mathrm{m}$, yang berarti hasil permukaan yang dicetak dengan $3 \mathrm{D}$ printer ini termasuk permukaan kasar sebagaimana pada tabel 1.

\section{Spesimen IV}

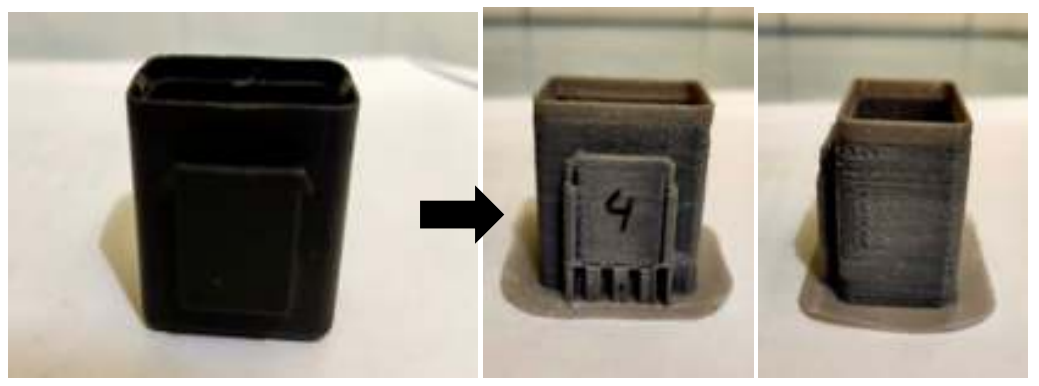

Parameter yang divariasikan dan diamati adalah sebagai berikut :

- Infil (pengisi) : 20\%

- Waktu Print pada software ultimaker cura : 27 menit

- Panjang PLA yang dibutuhkan dalam proses manufaktur : $2.73 \mathrm{~m}$

- Print speed : $100 \mathrm{~mm} / \mathrm{s}$

- Printing temperature $: 200^{\circ}$

- Panjang: $33 \mathrm{~mm}$

- Lebar: $22 \mathrm{~mm}$

- Tebal : $1.68 \mathrm{~mm}$

Dari hasil pengukuran kekasaran permukaan untuk spesimen IV sebanyak empat kali pengukuran seperti pada gambar 3, diperoleh rata-rata kekasaran untuk masing-masing pengukuran dan spesimen keempat adalah : 
1. Rata-rata kekasaran pada pengukuran di garis 1 adalah $\mathrm{Ra}=21,508 \mu \mathrm{m}$, Gambar 7 .

2. Rata-rata kekasaran pada pengukuran di garis 2 adalah $\mathrm{Ra}=21,452 \mu \mathrm{m}$.

3. Rata-rata kekasaran pada pengukuran di garis 3 adalah $\mathrm{Ra}=16,594 \mu \mathrm{m}$.

4. Rata-rata kekasaran pada pengukuran di garis 4 adalah $\mathrm{Ra}=18,858 \mu \mathrm{m}$.

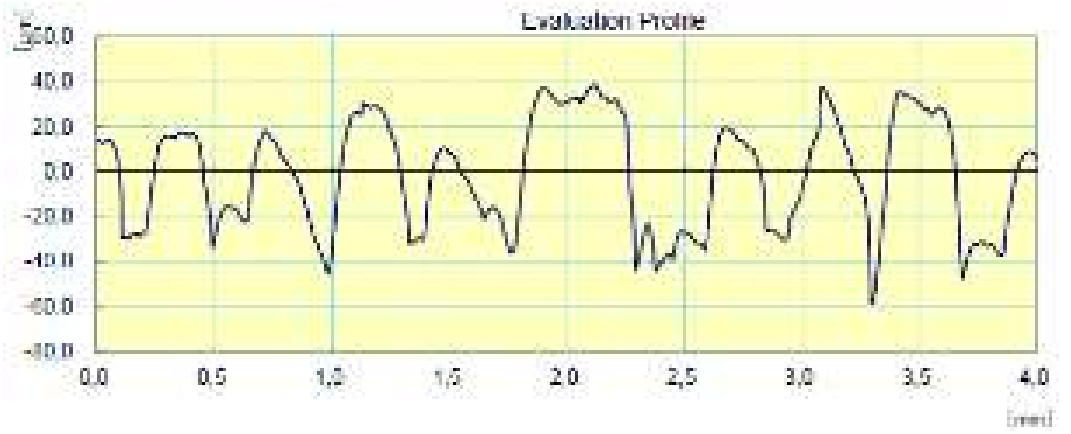

Gambar 7. Grafik rata-rata kekasaran pada pengukuran di garis $1(\mathrm{Ra}=21,508 \mu \mathrm{m})$ pada spesimen IV

Sehingga rata-rata kekasaran permukaan hasil pencetakan 3D untuk spesimen IV adalah $\mathrm{Ra}=19,626 \mu \mathrm{m}$, yang berarti hasil permukaan yang dicetak dengan 3D printer ini termasuk permukaan kasar sebagaimana pada tabel 1.

\section{Spesimen V}

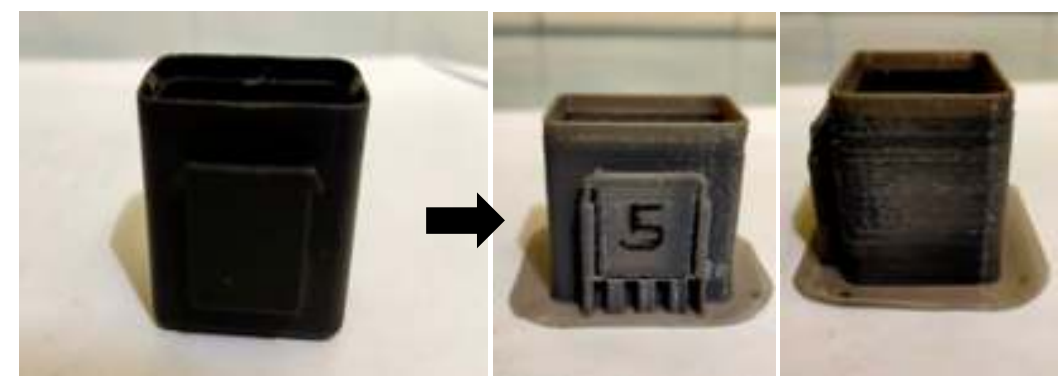

Parameter yang divariasikan dan diamati adalah sebagai berikut :

- Infil (pengisi) : 30\%

- Waktu Print pada software ultimaker cura : 27 menit

- Panjang PLA yang dibutuhkan dalam proses manufaktur : $2.73 \mathrm{~m}$

- Print speed : $120 \mathrm{~mm} / \mathrm{s}$

- Printing temperature : $190^{\circ}$

- Build plate temperature : $60^{\circ}$

- Panjang: $33 \mathrm{~mm}$

- Lebar: $22 \mathrm{~mm}$

- Tebal : $1.68 \mathrm{~mm}$

Dari hasil pengukuran kekasaran permukaan untuk spesimen V sebanyak empat kali pengukuran seperti pada gambar 3, diperoleh rata-rata kekasaran untuk masing-masing pengukuran dan spesimen kelima adalah :

1. Rata-rata kekasaran pada pengukuran di garis 1 adalah $\mathrm{Ra}=12,109 \mu \mathrm{m}$, Gambar 8 .

2. Rata-rata kekasaran pada pengukuran di garis 2 adalah $\mathrm{Ra}=12,594 \mu \mathrm{m}$.

3. Rata-rata kekasaran pada pengukuran di garis 3 adalah $\mathrm{Ra}=14,271 \mu \mathrm{m}$.

4. Rata-rata kekasaran pada pengukuran di garis 4 adalah $\mathrm{Ra}=13,920 \mu \mathrm{m}$. 


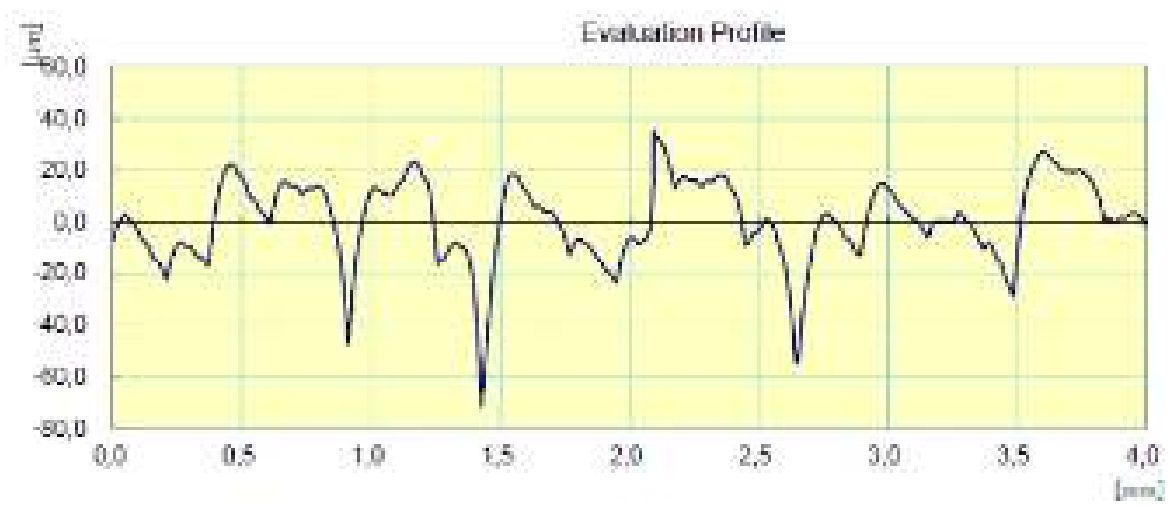

Gambar 8. Grafik rata-rata kekasaran pada pengukuran di garis $1(\mathrm{Ra}=12,109 \mu \mathrm{m})$ pada spesimen $\mathrm{V}$

Sehingga rata-rata kekasaran permukaan hasil pencetakan 3D untuk spesimen V adalah $\mathrm{Ra}=13,224 \mu \mathrm{m}$, yang berarti hasil permukaan yang dicetak dengan $3 \mathrm{D}$ printer ini termasuk permukaan kasar sebagaimana pada tabel 1 .

\section{Spesimen VI}
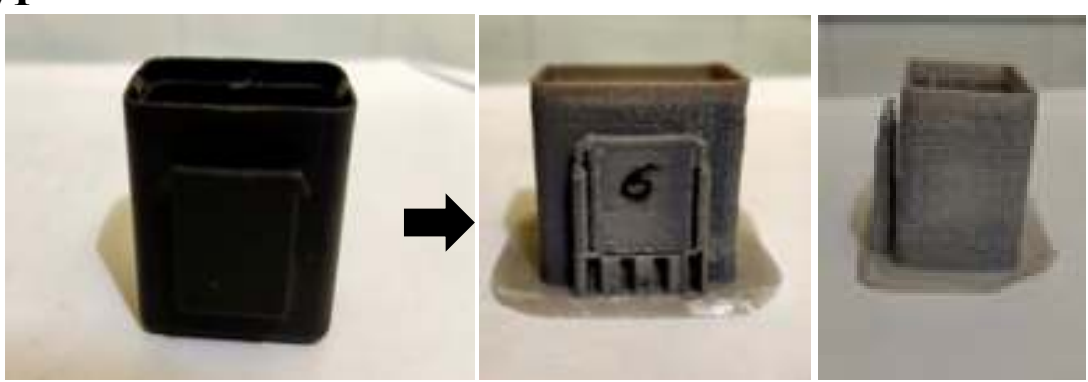

Parameter yang divariasikan dan diamati adalah sebagai berikut :

- Infil (pengisi) : 30\%

- Waktu Print pada software repetier host : 27 menit

- Panjang PLA yang dibutuhkan dalam proses manufaktur : $2.73 \mathrm{~m}$

- Print speed : $120 \mathrm{~mm} / \mathrm{s}$

- Printing temperature $: 200^{\circ}$

- Panjang: $33 \mathrm{~mm}$

- Lebar: $22 \mathrm{~mm}$

- Tebal : $1.69 \mathrm{~mm}$

Dari hasil pengukuran kekasaran permukaan untuk spesimen VI sebanyak empat kali pengukuran seperti pada gambar 3, diperoleh rata-rata kekasaran untuk masing-masing pengukuran dan spesimen keenam adalah :

1. Rata-rata kekasaran pada pengukuran di garis 1 adalah $\mathrm{Ra}=18,644 \mu \mathrm{m}$, Gambar 9 .

2. Rata-rata kekasaran pada pengukuran di garis 2 adalah $\mathrm{Ra}=14,866 \mu \mathrm{m}$.

3. Rata-rata kekasaran pada pengukuran di garis 3 adalah $\mathrm{Ra}=16,130 \mu \mathrm{m}$.

4. Rata-rata kekasaran pada pengukuran di garis 4 adalah $\mathrm{Ra}=14,866 \mu \mathrm{m}$. 


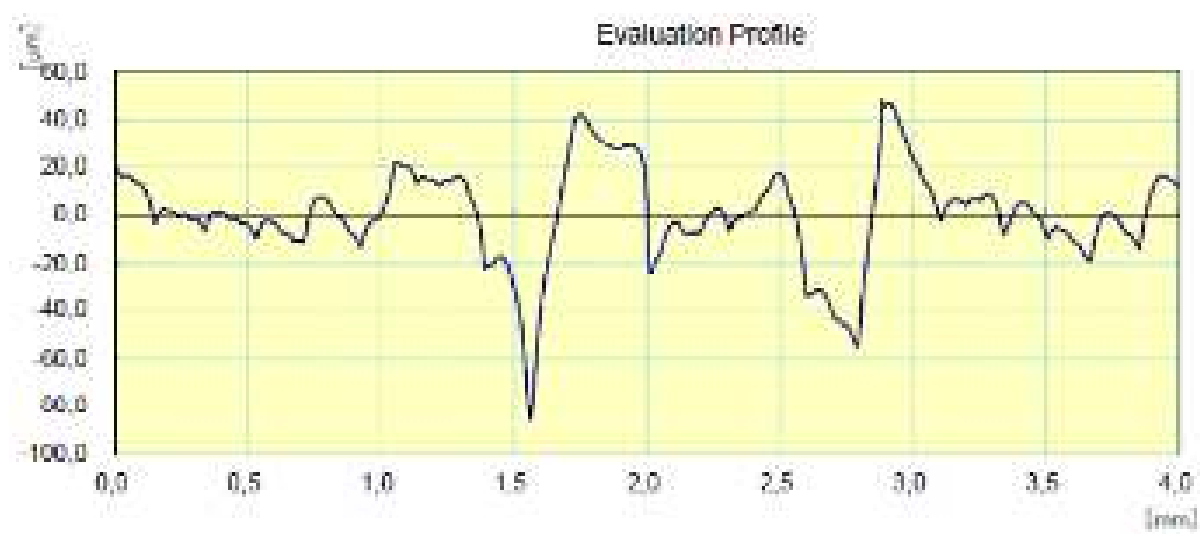

Gambar 9. Grafik rata-rata kekasaran pada pengukuran di garis $1(\mathrm{Ra}=18,644 \mu \mathrm{m})$ pada spesimen VI

Sehingga rata-rata kekasaran permukaan hasil pencetakan 3D untuk spesimen VI adalah $\mathrm{Ra}=16,127 \mu \mathrm{m}$, yang berarti hasil permukaan yang dicetak dengan 3D printer ini termasuk permukaan kasar sebagaimana pada tabel 1 .

\section{Spesimen VII}

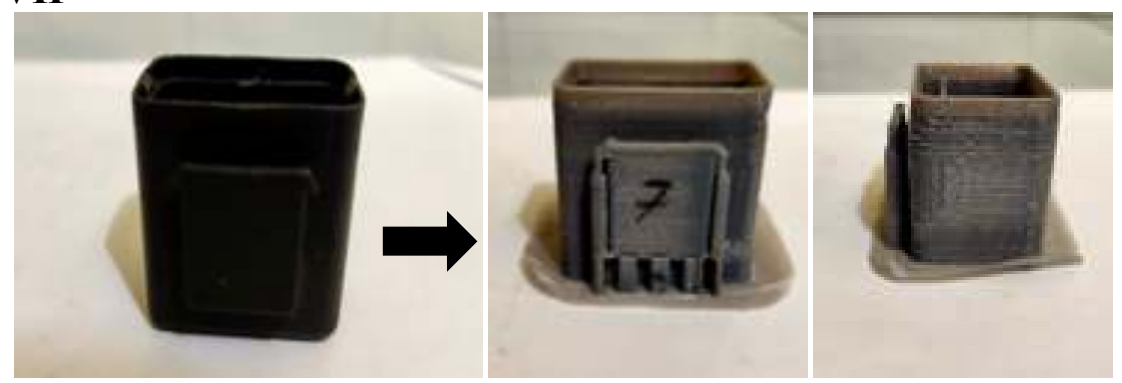

Parameter yang divariasikan dan diamati adalah sebagai berikut :

- Infil (pengisi) : 20\%

- Waktu Print pada software ultimaker cura : 27 menit

- Panjang PLA yang dibutuhkan dalam proses manufaktur : $2.73 \mathrm{~m}$

- Print speed : $120 \mathrm{~mm} / \mathrm{s}$

- Printing temperature $: 190^{\circ}$

- Panjang : $33 \mathrm{~mm}$

- Lebar: $22 \mathrm{~mm}$

- Tebal : $1.67 \mathrm{~mm}$

Dari hasil pengukuran kekasaran permukaan untuk spesimen VII sebanyak empat kali pengukuran seperti pada gambar 3, diperoleh rata-rata kekasaran untuk masing-masing pengukuran dan spesimen ketujuh adalah :

1. Rata-rata kekasaran pada pengukuran di garis 1 adalah $\mathrm{Ra}=15,455 \mu \mathrm{m}$, Gambar 10 .

2. Rata-rata kekasaran pada pengukuran di garis 2 adalah $\mathrm{Ra}=15,399 \mu \mathrm{m}$.

3. Rata-rata kekasaran pada pengukuran di garis 3 adalah $\mathrm{Ra}=17,164 \mu \mathrm{m}$.

4. Rata-rata kekasaran pada pengukuran di garis 4 adalah $\mathrm{Ra}=16,735 \mu \mathrm{m}$. 


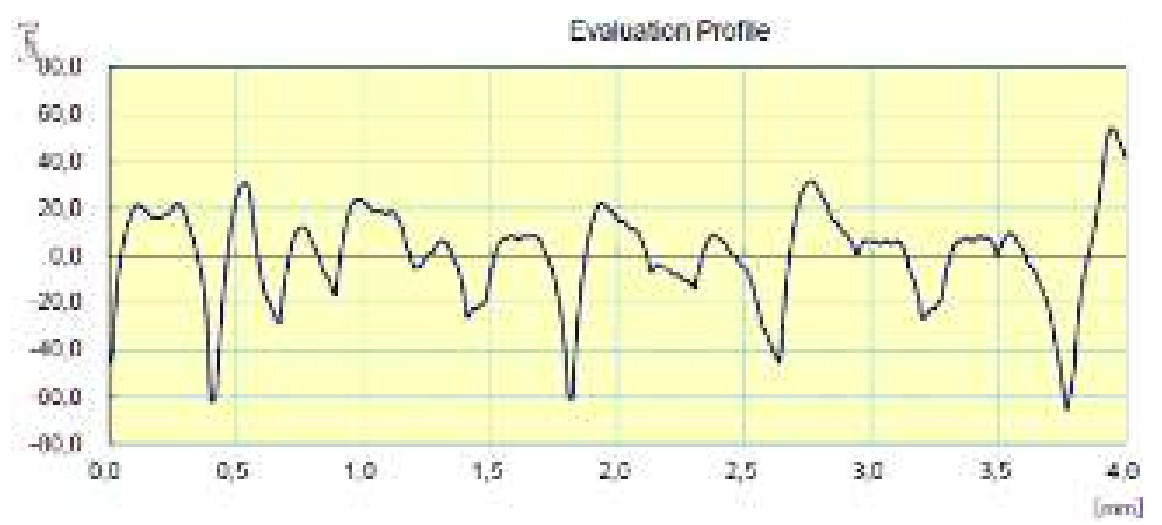

Gambar 10. Grafik rata-rata kekasaran pada pengukuran di garis $1(\mathrm{Ra}=15,445 \mu \mathrm{m})$ pada spesimen VII

Sehingga rata-rata kekasaran permukaan hasil pencetakan 3D untuk spesimen VII adalah $\mathrm{Ra}=16,188 \mu \mathrm{m}$, yang berarti hasil permukaan yang dicetak dengan $3 \mathrm{D}$ printer ini termasuk permukaan kasar sebagaimana pada tabel 1 .

\section{Spesimen VIII}

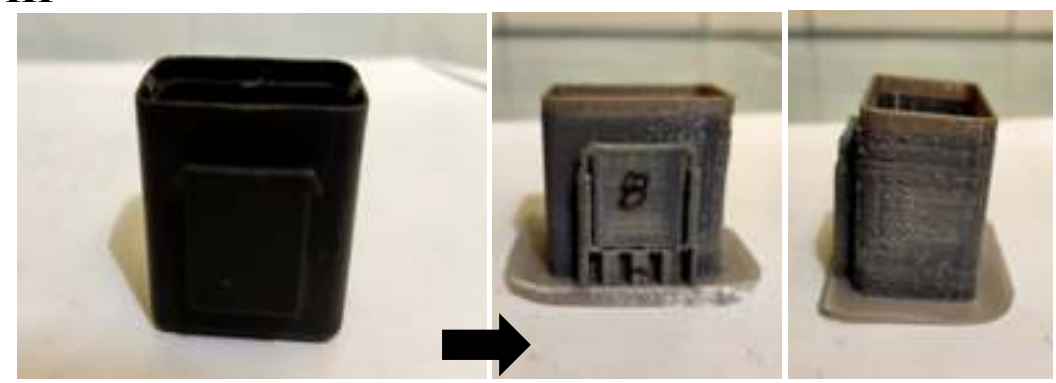

Parameter yang divariasikan dan diamati adalah sebagai berikut :

- Infil (pengisi) : 20\%

- Waktu Print pada software ultimaker cura : 27 menit

- Panjang PLA yang dibutuhkan dalam proses manufaktur : $2.73 \mathrm{~m}$

- Print speed : $120 \mathrm{~mm} / \mathrm{s}$

- Printing temperature $: 200^{\circ}$

- Panjang : $33 \mathrm{~mm}$

- Lebar: $22 \mathrm{~mm}$

- Tebal : $1.70 \mathrm{~mm}$

Dari hasil pengukuran kekasaran permukaan untuk spesimen VIII sebanyak empat kali pengukuran seperti pada gambar 3, diperoleh rata-rata kekasaran untuk masing-masing pengukuran dan spesimen kedelapan adalah :

1. Rata-rata kekasaran pada pengukuran di garis 1 adalah $\mathrm{Ra}=12,463 \mu \mathrm{m}$, Gambar 11 .

2. Rata-rata kekasaran pada pengukuran di garis 2 adalah $\mathrm{Ra}=13,046 \mu \mathrm{m}$.

3. Rata-rata kekasaran pada pengukuran di garis 3 adalah $\mathrm{Ra}=8,260 \mu \mathrm{m}$.

4. Rata-rata kekasaran pada pengukuran di garis 4 adalah $\mathrm{Ra}=11,392 \mu \mathrm{m}$. 


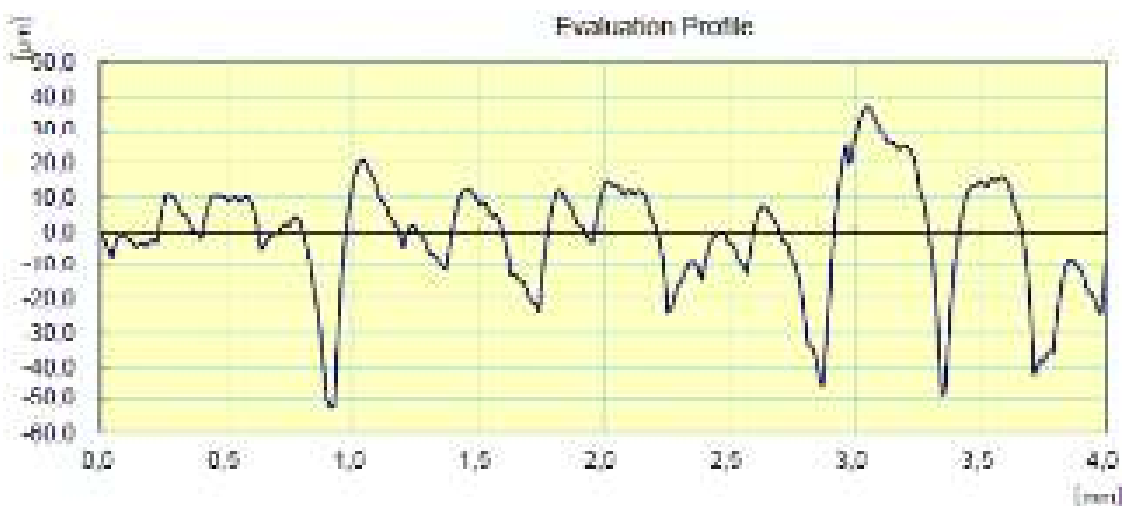

Gambar 11. Grafik rata-rata kekasaran pada pengukuran di garis $1(\mathrm{Ra}=12,463 \mu \mathrm{m})$ pada spesimen VIII

Sehingga rata-rata kekasaran permukaan hasil pencetakan 3D untuk spesimen VII adalah $\mathrm{Ra}=11,290 \mu \mathrm{m}$, yang berarti hasil permukaan yang dicetak dengan 3D printer ini termasuk permukaan kasar sebagaimana pada tabel 1 .

\section{KESIMPULAN}

Dari serangkaian percobaan dan pengujian pada proses pencetakan lampu sign sepeda motor dengan menggunakan 3D Printer dan filament PLA dengan beberapa variable diperoleh kesimpulan sebagai berikut:

- Seluruh produk hasil pencetakan memiliki sifat permukaan yang kasar

- Kecepatan pencetakan dan temperature nozel semakin tinggi serta persentase infill yang lebih rendahh akan menghasilkan kualitas produk yang lebih baik dan kekasaran yang lebih rendah/halus.

- Tingkat ketelitian geometri berkisar antara 0,91\% untuk dimensi panjang dan $7,73 \%$ untuk dimensi lebar dari produk.

\section{DAFTAR PUSTAKA}

[1]. Wohlers TT, "Wohlers report 2014: additive manufacturing and 3D printing state of the industry: annual worldwide progress report", Fort Collins, Wohlers Associates, 2014.

[2].Wandro J. Siregar, Richard A. M. Napitupulu, Parulian Siagian, "Desain dan manufaktur model piston Jupiter MX 135 cc dengan menggunakan 3D printer", SJoME Vol. I No. 2, Maret 2020.

[3]. Franando, Ahmad Zamheri, Fatahul Arifin, "Studi pembuatan bagian alat rehabilitasi penderita stroke dengan pendeekatan metode Taguchi", Machinery Jurnal Teknologi Terapan Vol.1 No.1, Agustus 2020.

[4]. Andik Aris Setiawan, Bayu Wiro Karuniawan, Nurvita Arumsari, "Optimasi parameter 3D printing terhadap keakuratan dimensi dan kekasaran permukaan produk menggunakan metode Taguchi Grey Relational Analysis", Proceedings conference on design manufacture engineering and its application, Politeknik Perkapalan Negeri Surabaya, Desember 2018. 
[5]. Sobron Lubis, Sofyan Djamil, Yolanda, "Pengaruh orientasi objek pada proses 3D Printing bahan polymer PLA dan ABS terhadap kekuatan tarik dan ketelitian dimensi produk", SINERGI Vol. 20, No. 1, Februari 2016.

[6].Hamid Abdillah, Ulikaryani, “Aplikasi 3D Printer Fused Deposite Material (FDM) pada pembuatan pola cor”, SINTEK JURNAL, Vol. 13 No. 2, Desember 2019.

[7].Ikhwan Taufik, Herru Santosa Budiono, Herianto, Deni Andriyansyah, "Pengaruh printing speed terhadap tingkat kekasaran permukaan hasil additive manufacturing dengan Polylactic Acid filament", Journal of Mechanical Engineering, Vol. 4, No. 2, September 2020

[8].Benny Haddli Irawan, Rahman Hakim, Hanifah Widiastuti, Domi Kamsyah1, Bambang Sahputra, "Pengaruh temperature nozzle dan base plate pada mesin Leapfrog Creatr 3D Printer terhadap density dan surface roughness material ABS", Jurnal Teknologi dan Riset Terapan (JATRA) Volume 1, Nomor 1 (Juni 2019) 